National Institute of Ochanography and Fisheries, Alex. Branch, Egypt.

\title{
FLAVOBACTERIUM COLUMNARE INFECTION IN CULTURED OREOCHROMIS NILOTICUS
}

(With One Table and 11 Figures)

By

SAFENAZ G. MOHAMED and W.D. SALEH*

* Dept. of Microbiology, Fac. of Agriculture, Cairo Univ., Egypt.

(Received at 25/2/2010)

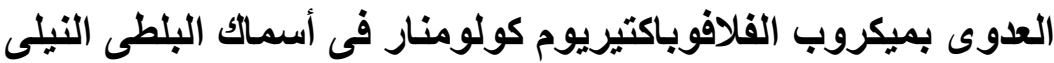

صافيناز جعاه محد أحمد ، وليا ضياء اللين صالح

ميكروب الفلافوباكتيريوم كولومنار المسبب لمرض الكولمنارز، هو من الميكروبات الممرضـة

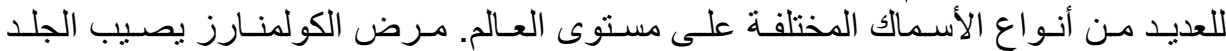

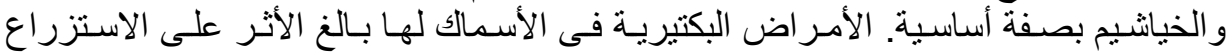

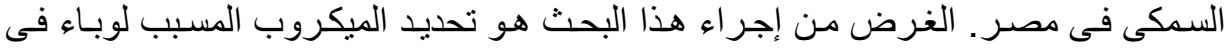

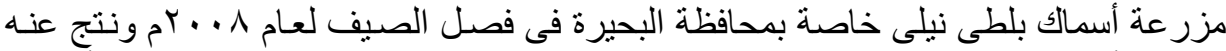

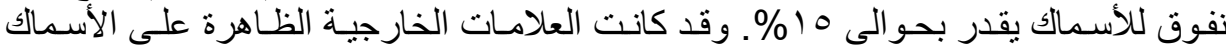

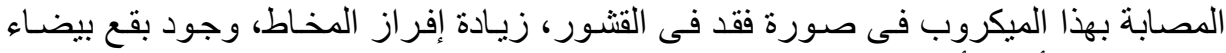

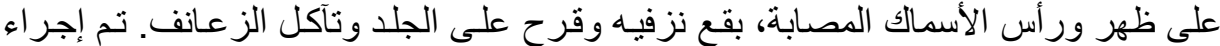

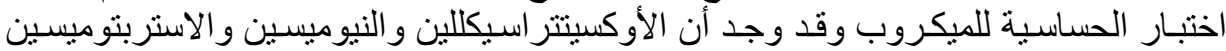
و الكلور امفينكول و الكاناميسين و اللنكوميسين و الايرثيو ميسين هى الأبين الأدويـة التى يمكن الاختينيار من بينها.

\section{SUMMARY}

Flavobacteruim columnare, causal agent of columnaris disease is pathogenic to many species of freshwater fish throughout the world. The columnaris disease occurred primary on the skin and gills. The Egyptian aquaculture industry is severely impacted by bacterial fish disease. The objective of the present study was to determine the causative agent of an outbreak caused mortality about 15\% among cultured Oreochromis niloticus in private fish farm in Behera governorate during late summer of 2008. The clinical signs of infected fish were loss of scales, excessive mucus, white spots on the back and head, skin ulcers, hemorrhage and fin erosion. The isolated bacteria developed characteristic rhizoid yellow pigmented colonies that showing swarming. They was gram-negative, filamentous bacteria exhibiting flexing movements Biochemical 
characterization proved that the isolated strain could be classified as F.columnare. The in vitro antibiotic sensitivity test showed that oxytetracycline, neomycin, streptomycin, chloramphenicol, kanamycin, lincomycin and erythromycin were drug of choices. Pathogenicity studies were performed on O.niloticus.

Key words: Flavobacterium columnare, Oreochromis niloticus, columnaris disease

\section{INTRODUCTION}

Serious losses only occur when pathogen and host are present in an environment which favor the occurrence of the disease. Columnaris disease is example of bacterial disease of fish affecting natural population in rivers or those from farms and hatcheries using freshwater (Austin and Austin, 1987).

If conditions are suitable, a wide variety of fish may be attacked by F.columnare and there appear to be no species or family restriction (Anderson and Conroy, 1969). F.columnare the causative agent of disease is a pathogen of worldwide important in freshwater fish.

In temperate fish, columnaris disease is recognized by the appearance of grayish white or yellow area of erosion, usually surrounded by a reddish hyperemic zone on the body surface or the gills of fish. When lesions occur around the dorsal fin, they are called saddle - back lesions (Austin and Austin, 1987). Outbreaks of columnaris disease are rarely spontaneous, but are influenced by a combination of environmental (temperature) and other factors stressful to the host, such as high stocking density, high level of ammonia and organic load (Wakabayashi, 1991; Shoemaker et al., 2003; Suomalainen et al., 2006).

In Egyptian aquaculture, many authors recorded columnaris disease in different fish species (Alyan, 1984; Badran and Eissa, 1991) where it induced severe economical losses by increasing the mortality.

The objective of this study was to determine the causes of severe clinical signs and mortality of fish during the outbreak through the isolation and identification of isolated bacteria, as well as its pathogenicity.

\section{MATERIALS and METHODS}

The naturally and experimentally infected Oreochromis niloticus were submitted to clinical and postmortem examination for any abnormalities as well as bacteriological, mycological and parasitological 
examination according to Amlacher (1970). Samples from skin mucus were collected from moribund fish during an outbreak in private fish farm from Elbehera governorate in July 2008. These samples were streaked on Trypticase soya agar (oxoid), and, Shieh agar (Shieh, 1980) supplemented with tobramycine at a concentration of $1 \mathrm{ug} / \mathrm{ml}$ (Decostere et al., 1997). For the supplemented Shieh agar, a membrane - filtered solution of tobramycin was added after sterilization.

To ensure sufficient moisture content plates with tobramycin were used within $24 \mathrm{~h}$. Plates were incubated at $30 \mathrm{C}$ and examined after 24, 36 and $48 \mathrm{~h}$.

Identification and characterization of bacteria isolated from diseased fish regarding morphology, growth, biochemical and antigenic characteristics were determined according to Decostere et al. (1998) and Shoemaker et al. (2008).

These characteristics were compared with those of the Flavobacterium. columnare reference strain NCB2254. Colonies of the bacteria isolated from diseased fish were checked on color, adherence to the agar and rhizoid edges. The suspected colonies were transferred to both Shieh agar and broth. Colour, size, Gram stained, gliding motility of the bacteria and growth aspect after $24 \mathrm{~h}$ were tested. Growth at different temperatures phenotypic and biochemical traits were carried out using the methods described by Bernarder and Grimont (1989) and compared with the reference strain NCB2254.

The isolated bacteria from the diseased fish was checked for the presence of $F$. columnare common antigen by slide agglutination using rabbit antiserum against type strain F.columnare NCB2254. The test was performed according to the method of Decostere et al. (1998).

The sensitivity of the isolated bacteria to different antibiotics was carried out using the dice diffusion technique according to Lennette et al. (1980).

\section{Pathogenicity test}

Apparently healthy O.niloticus (average body weight $60 \pm 5 \mathrm{~g}$ ) were kept in $100 \mathrm{~L}$ glass aquaria and used for experimental infection.

Prior to experiment 10 fish randomly selected were microbiologically examined and found to be culture negative for the tested isolate (Shoemaker et al., 2003).

Four groups of 15 fish were anesthetized with a solution containing $1 \mathrm{~g}$ of benzocaine (ethyl aminobenzoate) in $10 \mathrm{ml}$ ethanol. Three groups were intramuscularly inoculated with $0.2 \mathrm{ml}$ PBS containing $10^{6} \mathrm{CFU}$ of isolated bacteria. A fourth group was 
intramuscularly inoculated with $0.2 \mathrm{ml}$ sterile PBS and used as a control (Decostere et al., 1998). All groups were examined clinically 14 days after inoculation.

Mortalities were recorded daily for 14 days and used for culturing to conifirm $F$. columnare presence (Shoemaker et al., 2008).

Histopathological examination were carried out from organs of naturally and experimentally infected fish according to Robert (1978).

\section{RESULTS}

Clinical and postmortem changes in naturally infected Oreochromis niloticus, the signs of respiratory manifestation including gasping and rapid opercular movements were noticed with poor reflexes especially, escape one. Moribund and freshly dead fish showed discoloration off their back, fin rot, excessive mucus allover the body and superficial hemorrhagic ulcers (Fig.1). The skin around the mouth and opercula was blanched with congested gill lamellae. Slight congestion of liver and kidneys was observed.

The experimentally infected fish revealed the same clinical signs and postmortem lesions. Moreover the site of infection was ulcerated and hemorrhagic (Fig. 2). Some mortalities were occurred in naturally and $20 \%$ from experimentally infected O.niloticus.

Isolation and identification of Flavobacterium columnare strain isolated from diseased fish: Pure yellow - orange flat, rather small with rhizoid edges colonies were detected. The colonies were adherent to the agar showed swarming. The isolated bacteria was Gram. negative, filamentous and exhibiting flexing movement. When grown in flask a filamentary deposit was formed on the base and several thread - like structures were fixed at the side of the flask.

Optimal growth of the isolated bacteria occurred at 25-3C, but failed to grow in the presence of $1 \% \mathrm{NaCl}$.

Biochemical characteristics of isolated bacteria as well as from reference strain F.columnare were identical. Results are given in (Table 1). Carbohydrate metabolism was found negative. The isolated bacteria from diseased fish was agglutinated by serum against F.columnare reference strain. The isolation of bacteria in big quantity were obtained from skin mucus and gills. Moreover, isolation was also done from internal organs but in less quantity. There - isolation of injected F.columnare was positive from dead fish. Negative mycological examination was also occurred. Morovere, moderate monogenetic 
trematade and Trichodina infestation were found in examined diseased fish.Antibiotic sensitivity.

The in vitro antibiotic test showed that the isolated strain was sensitive to oxetracycline, streptomycin, neomycin, chloramphnicol, Kanamycin linecomycin and erythromycin .Both of colistin and sulfamethoxazole were found to be resistant.

\section{Histopathological alterations}

The naturally and experimentally infected fish showed more or less the same histopathological changes. The epidermis showed excessive necrosis and sloughing of the cells with exposure of the underlying dermis which exhibited severe acute inflammatory reaction represented by severe hyperemic and infiltration with leukocytes almost exclusively lymphocytes. Moreover, the underling musculature was involved where some myofibers showed variable degrees of sacroplasmolysis leading to myovacuolation (Fig. 3).

The gill arch showed diffuse severe edema resulting in dispersion of the fibrous connective tissue. Furthermore, there were congestion besides leukocytic and eosinophilic granular cell infiltration. The gill filaments showed slight edema at the base of the secondary lamellae together with moderate epithelia hyperplasia with club shape formation (Fig.4 and 5).

The majority of the liver hepatocytes appeared as signet ring indicating advanced fatty change, particularly the centrilobuar hepatocytes. In addition, other hepatocytes showed individual coagulative necrosis (Fig. 6 and 7).

The posterior kidney showed excessive focal dilatation of the convoluted tubules with eosinophilic hyaline cast. Such tubules became lined with flattened epithelium instead of the cuboidal one. Other tubules suffered from hydropic degeneration and vacuolation of their lining epithelium.Deposition of melanophores as brown patches around few arterioles was noticed (Fig. 8).

The white pulps of the spleen showed slight multifocal lymphoid cell depletion as a result of lymphocytic cell necrosis associated with hyperactivation of melanomacrophage centers.Other areas showed minute foci of coagulative necrosis of the splenic cortex (Fig 9 and 10).

The intestinal villi showed diffuse hyperplasia of the goblet cells (Fig11). Moreover, the submucosa showed severe congestion and edema. 
Table 1: Biochemical characteristics of strain isolated from diseased O.niloticus and reference strain NCB2254

\begin{tabular}{|l|c|}
\hline Oxidase & $2 / 2$ \\
Catalase production & $2 / 2$ \\
Flexirubin pigment & $2 / 2$ \\
No3 production & $2 / 2$ \\
H2 Sproduction & $2 / 2$ \\
Indol production & $0 / 2$ \\
Hydrolysis of & \\
Starch & $0 / 2$ \\
Gelatin & $2 / 2$ \\
Lecithin & $2 / 2$ \\
Carbohydrate fermentation & \\
Glucose & $0 / 2$ \\
Sucrose & $0 / 2$ \\
Lactose & $0 / 2$ \\
Maltose & $0 / 2$ \\
Mannitol & $0 / 2$ \\
Agglutination serum against & \\
F.columnare & $2 / 2$ \\
\hline
\end{tabular}


Assiut Vet. Med. J. Vol. 56 No. 125 April 2010 
Assiut Vet. Med. J. Vol. 56 No. 125 April 2010 
Assiut Vet. Med. J. Vol. 56 No. 125 April 2010 
Assiut Vet. Med. J. Vol. 56 No. 125 April 2010 
Assiut Vet. Med. J. Vol. 56 No. 125 April 2010 


\section{LEGEND OF FIGURES}

Fig.1: Naturally infected O.niloticus showing discoloration, excessive mucus and superficial hemorrhagic ulcers.

Fig.2: Experimentally infected O.niloticus showing discoloration, hemorrhagic ulcers of the site of injection and hemorrhage of the body.

Fig.3: Skin and underlying musculature of naturally infected O.niloticus showing variable degrees of sacroplasmolysis leading to myovaculation. $\mathrm{H} \& \mathrm{E}(\mathrm{x} 400)$.

Fig.4: Gills of naturally infected O.niloticus showing diffuse edema and leukocytic and eosinophilic granular cell infiltration. H\&E (X400).

Fig.5: Gills of experimentally infected O.niloticus showing club shape formation and moderate epithelia hyperplasia. $\mathrm{H} \& \mathrm{E}(\mathrm{x} 400)$.

Fig.6: Liver of experimentally infected O.niloticus showing heaptocytes appeared as signet ring indication fatty change. $\mathrm{H} \& \mathrm{E}(\mathrm{x} 400)$.

Fig.7: Liver of naturally infected O.niloticus showing coagulative necrosis of the hepatocyts. $\mathrm{H} \& \mathrm{E}(\mathrm{X} 250)$.

Fig.8: Kidneys of naturally infected O.niloticus showing hyaline cast, deposition of melanophores as brown patches around arterioles and hydropic degeneration of tubules. $\mathrm{H} \& \mathrm{E}(\mathrm{X} 400)$.

Fig.9: Spleen of naturally infected O.niloticus showing lymphoid cell depletion and multi foci of coagulate necrosis. H\&E(X400).

Fig.10: Spleen of experimentally infected O.niloticus showing hyper activation of melanomacrophage centers. $\mathrm{H} \& \mathrm{E}(\mathrm{X} 400)$.

Fig.11: Intestine of experimentally infected O.niloticus showing hyper plasia of the goblet cells and severe congestion and edema of sub-mucosa. $\mathrm{H} \& \mathrm{E}(\mathrm{X} 400)$.

\section{DISCUSSION}

Bacterial diseases are responsible for heavy mortality in both wild and cultured fish (Robert, 1989). Flavobacteriaum columnare, the causative agent of columnaris diseases, has been identified as one of the most problematic pathogen in freshwater farming industry (Suomalainen et al., 2005).

Pure bacterial isolate was recovered from O.niloticus during the outbreak as well as infestation with trichodina and monogenetic trematode. 
Biochemical and morphological characteristics of the isolated strain were identical to those of the reference $F$. columnarre strain. The same characters were reported by (Badran and Eissa 1991; Ellzey et al., 1997; Decostere et al., 1998).

Moreover, the isolated strain from diseased fish was agglutinated by serum against $F$.columnare common antigen, this confirmed that the isolated strain could be identified as F.columnare (Decostere et al., 1998).

However, columnaris diseases seems to be a problem among cultured of O.niloticus during hot season, probably because of the high temperature favour growth of many F.columnare strin (Post 1987; Younis 2000).

The clinical signs of naturally infected fish as well as experimentally one were excessive mucus erosion and necrosis of gill and skin of fish most typically around the dorsal fin, loss of scales hemorrhagic patches on the skin and progressive epidermal ulcer. These signs may be attributed to the adherence of the bacteria to gills and skin and the action of proteolytic enzyme produced by F.columnare (Decostere et al., 1999).

The presence of trichodina and monogenea might induce skin and gill abrasion which in turn facilitate the adherence and entrance of F.columnare to fish. Many studies have emphasized the possible role of parasites in enhancing infections of fish with secondary pathogens such as bacteria (Pylkko et al., 2006).

The pathways that can lead to such increased susceptibility might be direct, for example when an entrance route for bacteria is created due to epidermal or gills injuries by the parasite (Buchman and Bresciani 1997) or when a parasite act as a vector for a disease (Cusack and Cone, 1986). Also, the recorded parasites may enhanced F.columnare infection indirectly via decreased host immuno- competence (Bowers et al., 2000; Bandilla et al., 2006).

Concerning the mortalities in case of naturally and experimentally infected O.niloticus may be attributed to the osmotic and electrolyte imbalances as well as multiple changes in fish physiology leading to decrease disease resistance. (Tully and Nolan, 2002; Bandilla et al., 2006).

The successful induction of the disease experimentally leaves no doubt abut the potential pathogencity of isolated F.columnare. The fact that infection could occur following the presence in water contaminated with $F$.columnare confirm the invasive character of the organism. 
The histopathological changes in organs of infected fish were excessive necrosis and sloughing of the cells with exposure of the underline dermis which exhibited severe acute inflammatory reaction.

The gills showed severe edema and hyperplasia of the secondary lamellae Fatty changes and coagulative necrosis of liver cells, eosinophilic hyaline in convoluted tubules and hyper - activation of goblet cells of intestine were recorded. Moreover, activation of melanomacroplage centers.

These changes were previously reported by Ellzey et al. (1997) and Younis (2000). This work raised abut the importance of F.columnare as a cause of serious disease among cultured O.niloticus. Moreover, the role of the ectoparasite infestation in prevalence of the disease was confirmed.

\section{REFERENCES}

Abd El-Aziz, E.S. (1988): Some studies on bacterial agents causing taill and fins rot among freshwater fish in Egypt. M.Sc. Thesis, Fac. Vet. Med. Cairo, Univ.

Alyan, S. (1984): Some studies on gill infection in freshwater fish of Upper Egypt. Msc. Thesis, Fac. of Vet. Med. Assiut Univ.

Amlacher, E. (1970): Textbook of Fish Diseases T.E.S Publication, N. Jersey USA.P145-177.

Anderson, J.I. and Conrony, D.A. (1969): Myxobacteria as fish pathogen. J. Appl. Bact., 32: 30-39.

Arias, C.R.; Abernathy, J.W. and Liu, Z. (2006): Combined used of 16S ribosomal DNA and automated ribosomal intergenic spacer analysis to study the bacterial community in catfish ponds. Lett. Appl. Microbiol. 43: 287-292.

Austin, B. and Austin, D.A. (1987): Bacterial Fish Pathogen. In Diseaes in Farmed and Wild Fish. P. 225-249.

Badran, A.F. and Eissa I.A. (1991): Studies on bacterial diseases amang cultured freshwater fish Oreochromis niloticus in relation to the incidence of bacterial pathogens at Ismalia governorate. J. Egypt. Vet. Med. Ass., 51(4): 837-847.

Bandilla, M.; Valtonen, E.T.; Suomalainen, L.R.; Aphalo, P.J. and Hakalahti, T. (2006): A link between ectoparasite infection and susceptibility to bacterial disease in rainbow trout. Int. J. of Parasitology 36: 987-991. 
Bernaret, J.F. and Grimont, P.A.D. (1989): Deoxyribonucleic acid relatedness and phenotypic characterization of Flavobacterium columnaris sp. nov., nom. rev, Flexibacter s. nov, nom. rev, and Flexibacter. maritimus Int J. Syst.Bacterial., 346-354 psychrofilussp.

Bowers, J.M.; Mustafa, A.; Sepeare, D.J.; Conboy, G.A.; Brimacombe, M., Sims, D.E. and Burka, J.F. (2002): The physiological response of Atlantic salmon, Salmo solae L., Atlantic salmon, L., to a single experimental challege with sea lice, lepeophtherius salmonis. J. Fish Dis 23: 165-172.

Buchann, K. and Bresciani, J. (1997): Parasitic infections in pondreared rainbow trout in Denmark. Dis. Aquat. Organ. 28: 125138.

Cusack, R, and Cone, D.K. (1986): Areview of parasites as vectors of viral and bacterial disease of fish. J. Fish Dis P, 169-171.

Decostere, A.; Haesebrouk, F. and Devriese, L.A. (1997): Shieh medium supplemented with tobramycin for selective isolation of Flavobacterium columnaris from diseased fish. J. Clin. Microb. 35: 322-324.

Decostere, A.; Haesebrouck, F. and Devriese, L.A. (1998): Characterition of four Flavobacterium columnare strains isolated from tropical fish. Vet. Microbiol. 62: 35-45.

Ellzey, A.S.; Bardan, J.; El-Meleigy and Mayberry, G. (1997): Pathological and electron microscpic studies on columnaris disease among carp (Cyprinus carpio). Zag. Vet. J., 25(1): 142-148.

Post, G. (1987): Text book of Fish Heath. T.F.H. Publication Ascot, Berkshire, PP: 51-56.

Pyllkko, P.; Sudmalainen, L.R.; Tilrola, M. and Valtones, E.T. (2006): Evidence of enhanced bacterial invasion during Diplostomum spathaceum infection in European grayling Thymallus thymallus (L). J. Fish Dis. 29: 79-86.

Roberts, R.J. (1978): Fish Pathology. $1^{\text {st }}$ Bailliere, Tindall, London, P. 146-186.

Robert, R.J. (1989): Fish Pathology. $2^{\text {nd }}$ Ed Balliere, Tindall, Londan England p.264-273.

Shieh, H.S. (1980): Studies on the nuturition of a fish pathogen, Flexibacter columnaris, Microbios. Lett. 13: 129-133. 
Shoemaker, C.A.; Arias, C.R.; Klesius, P.H. and Welker, T.l. (2003): Technique for identifying Flavobacteriun columanare using whole - cell fatty acid profiles. J. Aqua Anim. Health, 17: 267-274.

Shoemaker, C.A.; Oivares, O.; Arias, C.R. and Klesius, PH. (2008): Flavobacterium columnare genmover influnces mortality in channel catfish (Ictalurus punctatus). Vet. Microbiol. 127: 353-359.

Stoskopf, M.K. (1993): Fish Medicine, W.b. Sounders Company, Harcourt, Brace Jovanich, Inc. London P. 272-279.

Suomalainen, L.R.; Tiirola, M.A. and Valtonen, E.T. (2005): Influence of rearing condition on Flavabacterium columnare infection of rainbow trout, Oncorhynchus mykiss (Walbaum). J. Fish Dis. 28: 271-277.

Tully, O. and Nolan, D.T. (2002): A review of the population biology and host-parasite interaction of the sea louse lepeoptherius salmonis (Copepoda: Caligidae). Parasitology 124, s 165-s182.

Wakabayashi, H. (1991): Effect of environmental conditions on the infectivety of Flexibacter columnaris to fish. J. Fish Diseases 14: 279-290.

Younis, A.A. (2000): Some studies on columnaris disease in freshwater fish. M.V.SC Thesis, Fac. of Vet. Med. Alex. Univ., Egypt. 
Assiut Vet. Med. J. Vol. 56 No. 125 April 2010 